\title{
INFLUENCE OF RAILING STIFFNESS ON SINGLE-SPAN TWO- LANE STEEL GIRDER BRIDGES
}

\author{
Wassim Nasr Eddine ${ }^{1}$, Kassim Tarhini ${ }^{2}$ and $*$ Mounir Mabsout ${ }^{3}$ \\ ${ }^{1}$ Dept. of Civil and Environmental Engineering, Rutgers Univ., New Jersey, USA; formerly Dept. of Civil \\ and Environmental Engineering, Amer. Univ. of Beirut, Lebanon; ${ }^{2}$ Dept. of Civil Engineering, U.S. Coast \\ Guard Academy, New London, CT, USA; ${ }^{3}$ Dept. of Civil and Environmental Engineering, Amer. Univ. of \\ Beirut, Lebanon
}

*Corresponding Author, Received: 15 April 2019, Revised: 03 Dec. 2019, Accepted: 22 March 2020

\begin{abstract}
The presence of railings or parapets acting integrally with the concrete deck placed on steel girders has the effect of stiffening and therefore altering the lateral wheel load distribution on highway bridges. The American Association of State Highway and Transportation Officials (AASHTO) Standard Specifications for Highway Bridges and AASHTO LRFD Bridge Design Specifications procedures do not account for the presence of railings when evaluating the load-carrying capacity of highway bridges. This paper presents a parametric study using 3D finite element analysis to investigate the influence of railing stiffness on one-span, two-lane steel girder bridges. Railings of different sizes were placed on one or both sides of the bridge deck, in combination with various span lengths and girders spacing. AASHTO HS20 design trucks were placed longitudinally and transversally in order to produce maximum longitudinal bending moments in the steel girders. The wheel load distribution obtained from finite element analysis at the critical section of each bridge were compared with the AASHTO procedures and with reference cases for bridges without railing. This study confirmed that the presence of concrete railings modeled and built integrally with the deck tends to stiffen the bridge superstructure. Further, the study quantified the effect of railing in increasing the load-carrying capacity of steel bridges. The results of this research will therefore assist structural engineers in better designing new steel girder bridges and/or evaluating more precisely the load-carrying capacity of existing bridges with railings of different sizes. Bridge engineers can consider adding or stiffening railings/parapets as a practical method for strengthening existing steel girder bridges.
\end{abstract}

Keywords: Steel girder bridges, Railings or parapets stiffness, AASHTO procedures, Finite-element analysis, Wheel load distribution factor, Load-carrying capacity.

\section{INTRODUCTION}

A common type of highway bridge deck is a reinforced concrete slab placed on steel I-beams that is referred to as a steel girder bridge. The analysis and design of highway bridges in the United States must conform to the American Association of State Highway and Transportation Officials (AASHTO) procedures, either to the Standard Specifications for Highway Bridges (2002) prior to 2007 - thereafter referred to as AASHTO Standard [1], or to the current Load and Resistance Factor Design (LRFD) Specifications (2014) - thereafter referred to as AASHTO LRFD [2]. Typically, the analysis of a three-dimensional (3D) bridge superstructure is reduced to the analysis of a two-dimensional (2D) single girder by using a wheel load distribution factor (DF). The current AASHTO wheel load distribution factors (Standard or LRFD) do not consider the influence of raised sidewalks and/or railings that are built integrally with the bridge deck, nor their effect on the increase of the bridge's stiffness and its loadcarrying capacity.

A previous study reported the results of a parametric study that investigated, using finite element analysis (FEA), of various modeling techniques on one-span, two-lane, simply supported, composite steel girder bridges without the presence of sidewalks or railings [3]. In this study, the span length and girder spacing were varied within practical ranges, and the FEA results were used to calculate the longitudinal bending moments and wheel load distribution factors in the steel girders for the composite slabs, which were compared with AASHTO procedures. A follow-up study extended the latter analysis to investigate the influence of sidewalks and railings of standard sizes on wheel load distribution for the same bridges [4]. The presence of sidewalks and railings was shown to increase the stiffness of the superstructure and improve the loadcarrying capacity of steel bridges by as much as $30 \%$.

Another study investigated the influence of secondary elements and deck cracking on the lateral load distribution of steel girder bridges [5]. The presence of secondary elements such as lateral bracing and parapets produces load distribution factors up to $40 \%$ lower than the AASHTO LRFD values. Other work investigated the effect of parapets 
and bridge aspect ratio on live-load moment distribution in bridge girders [6]. The finite element analysis was used to investigate 34 two-span continuous bridges with different skew angles and overhang lengths. The presence of parapets was shown to reduce the wheel load distribution factors by as much as $36 \%$ and $13 \%$ for exterior and interior girders, respectively. Another research reported the parapet strength and contribution to live-load response for permit super-load passages were tested [7]. The results of this study showed that girder distribution factors (GDFs) can be decreased by as much as $30 \%$, depending on the stiffness of the girders and the transverse truck position if the parapets are included in the analysis. The effect of secondary elements on load distribution in prestressed bridge girders was examined showing the effect of including barriers (railings) in calculating the wheel load distribution and bending moments in girders [8].

This paper builds on the previously published research, namely in [3-4], by performing a parametric study investigating the influence of railing stiffness on wheel load distribution in simply-supported, onespan, two-lane steel girder bridges. The results of 240 bridge cases that are modeled using FEA are presented in this paper. The various bridge parameters investigated in this study are the span length, girder spacing, and various railings stiffness and configurations, subject to HS20 truck loadings positioned transversally and longitudinally in order to produce the maximum longitudinal live load bending moments. Parapets or railings are assumed to be placed on either edge or both edges of the bridge deck, built integrally with the concrete slabs that is placed over steel girders under composite action. The effect of railing stiffness on the maximum live load wheel load distribution factors are assessed by calculating and comparing the FEA bending moments with both AASHTO Standard and LRFD, as well as with the reference bridge cases without railing.

\section{AASHTO STANDARD AND LRFD PROCEDURES}

The AASHTO Standard [1] specifications specify the load distribution factor for a steel girder to be a function of the girder spacing only. The use of distribution factors reduces the three-dimensional (3D) bridge deck analysis to a two-dimensional (2D) beam analysis and design process subject to AASHTO HS20 loadings. Typically, AASHTO design wheel loads are positioned on a 2D girder using influence lines to produce the maximum design live load moment, which is then multiplied by an empirical wheel load distribution factor (DF) such as $\mathrm{S} / 5.5$, where $\mathrm{S}$ is the girder spacing in feet $(\mathrm{S} / 1676$, where $\mathrm{S}$ is in millimeters) - thereafter referred to as " $\mathrm{S} / 5.5$ " formula. If the girder spacing is greater than
$14 \mathrm{ft}(4.27 \mathrm{~m})$, AASHTO recommends the use of simple beam distribution for estimating the wheel load distribution factor. This AASHTO Standard procedure has been criticized for being conservative due to its simplistic load distribution factors.

The AASHTO LRFD [2] specifications introduced relatively new wheel load distribution factors based on published research in the last few decades. AASHTO LRFD wheel load distribution formulae presented in Table 4.6.2.2.2b-1 account for parameters such as span length, girder spacing, and cross-sectional properties of the bridge deck. The wheel load distribution factor for bending moment in two-lane steel girder bridges is, in Imperial units:

$g=0.075+\left(\frac{S}{9.5}\right)^{0.6}\left(\frac{S}{L}\right)^{0.2}\left[\frac{K_{g}}{12.0 L t_{s}{ }^{3}}\right]^{0.1}$

The equivalent equation in SI units is:

$g=0.075+\left(\frac{S}{2,900}\right)^{0.6}\left(\frac{S}{L}\right)^{0.2}\left[\frac{K_{g}}{L t_{s}{ }^{3}}\right]^{0.1}$

where:

$S=$ girder spacing ( $\mathrm{ft}, 3.5 \leq S \leq 16.0)$ or $(\mathrm{mm}, 1,100$ $\leq S \leq 4,900)$

$L=$ span length of beam ( $\mathrm{ft}, 20 \leq L \leq 240$ ) or (mm, $6,000 \leq L \leq 73,000)$

$K_{g}=$ longitudinal stiffness parameter $\left(\mathrm{in}^{4}, 10,000 \leq K_{g}\right.$ $\leq 7,000,000)$ or $\left(\mathrm{mm}^{4}, 4 \times 10^{9} \leq K_{g} \leq 3 \times 10^{12}\right)$

$=n\left(I+A e_{g}^{2}\right)$

$n=$ modular ratio between beam and deck material

$I=$ moment of inertia of beam $\left(\right.$ in $^{4}$ or $\left.\mathrm{mm}^{4}\right)$

$A=$ girder gross area $\left(\mathrm{in}^{2}\right.$ or $\left.\mathrm{mm}^{2}\right)$

$e_{g}=$ distance between the centers of gravity of the basic beam and deck (in or mm)

$t_{s}=$ depth of concrete slab (in, $\left.4.5 \leq t_{s} \leq 12.0\right)$ or (mm, $\left.110 \leq t_{s} \leq 300\right)$

Equation (1) is recommended for highway bridges with at least two lanes, composite or non-composite, single- and multi-span steel girder bridges. Even though this equation was recommended for bridge decks with at least four girders, the presence of three girders in a bridge deck was also investigated in this paper and the FEA results were evaluated and compared with Eq. (1).

\section{BRIDGE CASES AND LOADING}

Typical one-span, simply supported, two-lane straight steel girder bridges were selected for this parametric FEA investigation. The bridge deck consisted of a 7.5 inches $(190 \mathrm{~mm})$ reinforced concrete slab thick supported by structural steel girders (W36x160). The various span lengths " $L$ " considered in this study were 40, 60, 80, 100, and 120 $\mathrm{ft}(12,18,24,30$, and $36 \mathrm{~m})$. The girder spacing " $S$ " was set at 6,8 , and $12 \mathrm{ft}(1.8,2.4$, and $3.6 \mathrm{~m})$. A 


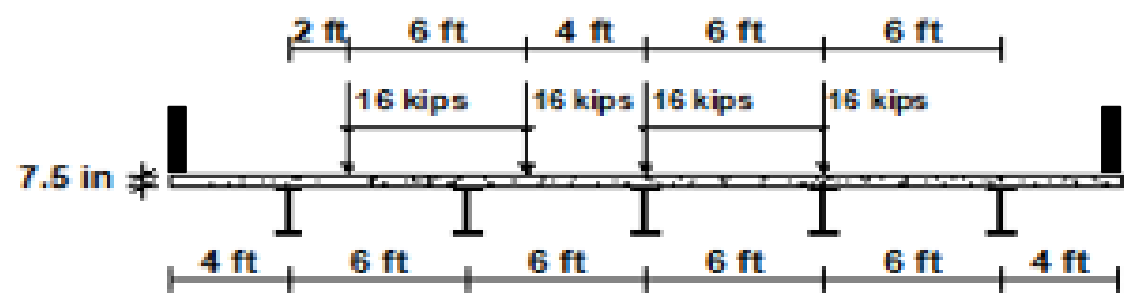

Fig. 1 Typical two-lane bridge cross-section with standard railings on both edges (x1, 2R) and HS20 trucks loading

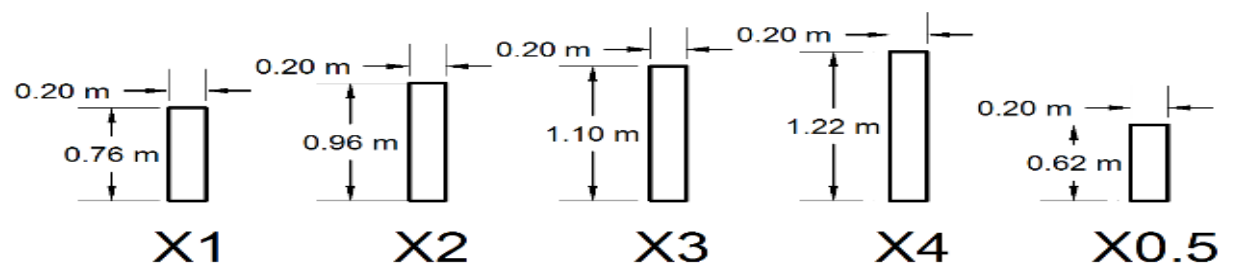

Fig. 2 Various railing sizes (x1, x2, x3, x4, x0.5)

standard lane width of $12 \mathrm{ft}$ (3.6 m) was used with a shoulder width of $4 \mathrm{ft}(1.2 \mathrm{~m})$, and the overall bridge slab width was $32 \mathrm{ft}(9.6 \mathrm{~m})$ for two lanes with a shoulder on each side. These dimensions accommodate the possible presence of sidewalks and/or railings on the bridge deck. A typical bridge cross-section with $6 \mathrm{ft}(1.8 \mathrm{~m})$ girder spacing is shown in Fig. 1.

A reinforced concrete railing or parapet, 8 inches (200 mm) thick by 30 inches $(760 \mathrm{~mm})$ high, was selected as the standard railing (labeled as x1) and placed on the left, right, and on both sides of the deck (labeled respectively as RL, RR, and 2R) for all bridge combination parameters considered, as shown in Fig. 1 for the case (2R). Four additional railing sizes were considered in this study by varying the stiffness to half, double, triple and quadruple the standard railing stiffness (labeled respectively as $\mathrm{x} 0.5$, $\mathrm{x} 2, \mathrm{x} 3$, and $\mathrm{x} 4$ ), and all railings cross-sections are shown in Fig. 2. It was assumed that the railings were properly reinforced and connected integrally to the bridge deck in order to transmit the shear forces, bending moments, and to act integrally with the superstructure. Reference bridge decks with no railing were also analyzed using for comparative analysis (labeled as NoR).

The bridge live loadings considered in this investigation were limited to the AASHTO Standard [1] of either applying AASHTO HS20 design truck or a train of HS20 trucks depending on the span length. The single HS20 truck has a total weight of 72 Kips (324 kN), distributed over two rear axles of 32 Kips $(144 \mathrm{kN})$ each and one front axle of 8 Kips (36 kN), with a distance of $14 \mathrm{ft}(4.2 \mathrm{~m})$. For the train of trucks, HS20 trucks were placed longitudinally in each lane of a given bridge, with a spacing of $30 \mathrm{ft}(9 \mathrm{~m})$ separating each of the trucks. Only one truck per lane can fit on a given bridge, and the design truck or train of trucks using influence lines in order to achieve the most severe live loading conditions. In all cases, the trucks in multiple lanes assumed to be traveling in the same direction. Transversally, the AASHTO HS20 design trucks were positioned side-by-side on the bridge superstructures with a distance of $4 \mathrm{ft}(1.2 \mathrm{~m})$ between the loading points. Note that the transverse position of the trucks was selected in order to produce the most severe loading conditions on the bridge to result in the maximum bending moment in the critical girder, as shown for the $6 \mathrm{ft}(1.8 \mathrm{~m})$ girder spacing in Fig. 1.

Typical material properties used in modeling the bridge superstructure were normal-strength reinforced concrete with compressive strength of 4,000 psi (27.5 MPa), modulus of elasticity of $3.6 \times 10^{6}$ psi (24.8 GPa), and Poisson's ratio of 0.20 . The modulus of elasticity of steel beams were selected to be $29 \times 10^{6}$ psi (200 GPa).

\section{FINITE ELEMENT MODELING}

The 3D-FEA model and mesh discretization adopted to analyze the 240 bridge cases considered is based on previous studies reported earlier [3]-[4] using the general FEA program SAP2000 [9]. This study considered all elements to be linearly elastic and the analysis assumed small deformations and deflections.

The concrete slab was modeled using quadrilateral 2x2 $\mathrm{ft}(0.60 \times 0.60 \mathrm{~m})$ shell elements (SHELL, with 6 degrees of freedom at each node) and the steel girders were idealized as space-frame elements (FRAME, with six degrees of freedom at each node). The railings were also modeled as concentric space-frame elements with a moment of inertia and stiffness equivalent to an eccentric element applied on top of the slab [4]. Hinges were 


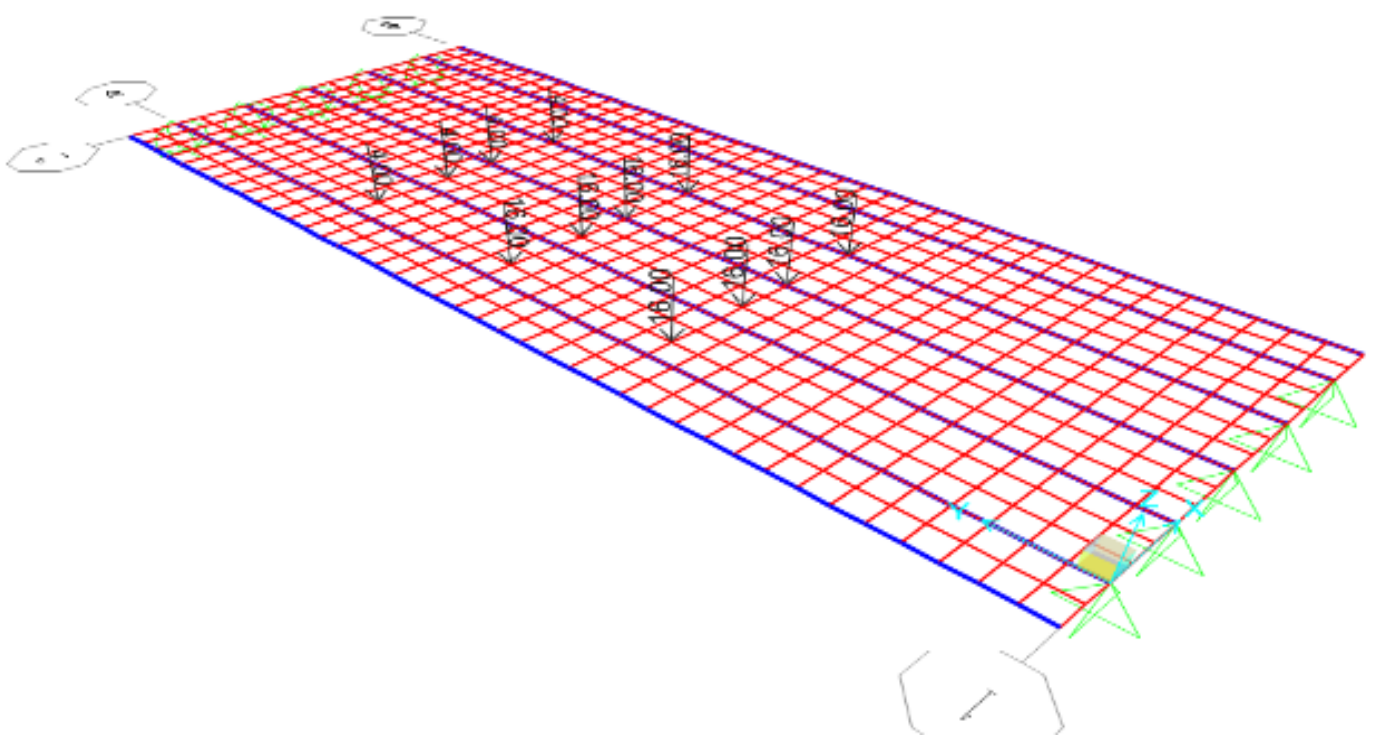

Fig. 3 Typical 3D-FEA model of a two-lane bridge with standard railings on both edges (x1, 2R) and HS20 trucks loading

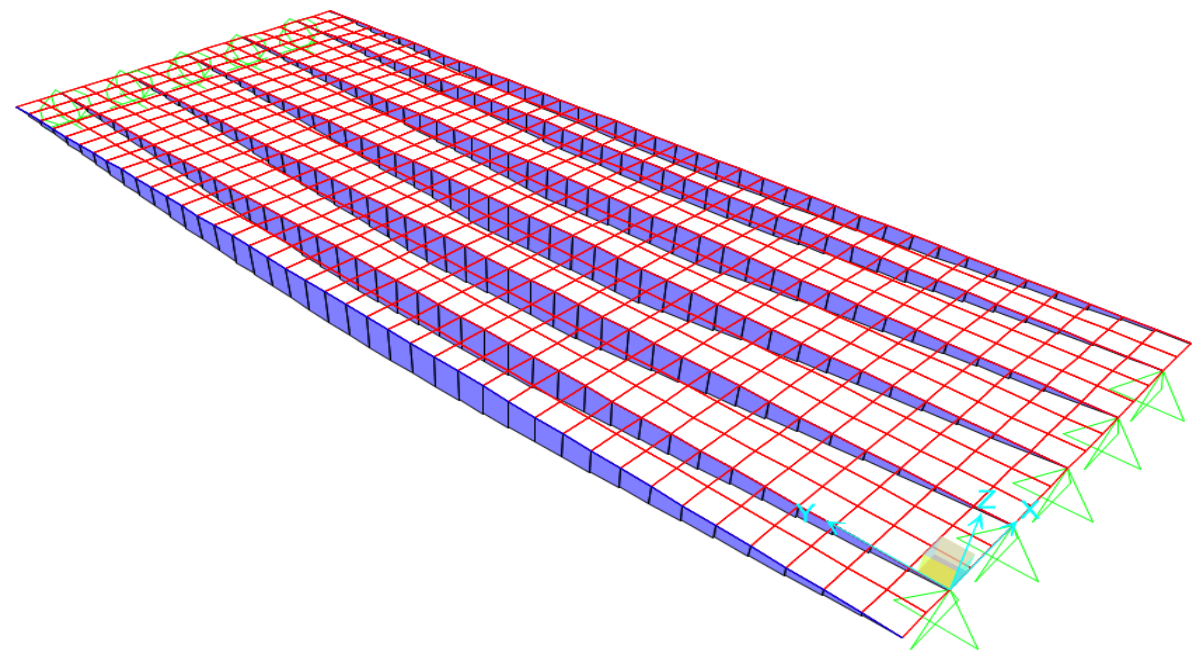

Fig. 4 Typical girders moment diagrams in a two-lane bridge with standard railings on both edges $(\mathrm{x} 1,2 \mathrm{R})$ and HS20 trucks loading

assigned at one bearing location and rollers at the other to simulate the simple support conditions. AASHTO HS20 wheel loads were applied at isolated nodes, located longitudinally and transversally in order to produce maximum longitudinal bending moments. Figure 3 shows a typical 3D-FEA model for a two-lane bridge with span length of $80 \mathrm{ft}(24 \mathrm{~m})$ and girder spacing of $6 \mathrm{ft}(1.8 \mathrm{~m})$ subjected to AASHTO HS20 truck loading.

The 3D-FEA results reported are stresses or moments for the slab shell elements and moments for the girders and railings frame elements. The moments in the girders were calculated using two parts: (a) the bending moment contribution of the tributary or effective concrete slab, and (b) the bending moment in the steel girder element. Figure 4 shows the longitudinal bending moment distribution in all girders (no slab contribution) and railings for the same bridge case shown in Fig. 3.

\section{SUMMARY OF RESULTS}

The maximum FEA moments from each and all girders, with the corresponding moments contributed from the slabs and railings, are obtained for all the 240 bridge cases analyzed. The presence of railings were considered as a part of the concrete section that contributed to the exterior girders in resisting wheel loads which tends to overestimate those moments as compared to interior girders. However, when considering girder and slab without railings, the moments in the critical interior girder will be larger than in exterior girders, and will therefore be considered as the effective moments used for design. 
Table 1 FEA moments in girders, slabs, and railings for two-lane bridges with $80 \mathrm{ft}$ span, $6 \mathrm{ft}$ girder spacing, and standard railings (x1)

\begin{tabular}{|c|c|c|c|c|c|c|c|c|}
\hline \multicolumn{9}{|c|}{ Bending Moments (kip-ft), Two Lanes, L=80 ft, S=6ft, Standard Railings (x1) } \\
\hline Case & Zone & Girder 1 & Girder 2 & Girder 3 & Girder 4 & Girder 5 & Total & Max \\
\hline \multirow{4}{*}{ NoR } & Girder & 514.8 & 503.3 & 472.9 & 405.4 & 311.5 & 2208.0 & 514.8 \\
\hline & Slab & 28.1 & 30.4 & 28.2 & 20.9 & 14.0 & 121.6 & \\
\hline & Railling & 0.0 & 0.0 & 0.0 & 0.0 & 0.0 & 0.0 & \\
\hline & Total & 542.9 & 533.7 & 501.1 & 426.4 & 325.5 & 2329.6 & 533.7 \\
\hline \multirow{4}{*}{ RL } & Girder & 348.3 & 407.9 & 429.0 & 398.8 & 336.2 & 1920.1 & 429.0 \\
\hline & Slab & 22.4 & 29.4 & 28.7 & 21.9 & 15.5 & 118.0 & \\
\hline & Railling & 291.5 & 0.0 & 0.0 & 0.0 & 0.0 & 291.5 & \\
\hline & Total & 662.1 & 437.4 & 457.7 & 420.7 & 351.7 & 2329.6 & 457.7 \\
\hline \multirow{4}{*}{$\mathrm{RR}$} & Girder & 526.6 & 498.2 & 447.6 & 353.9 & 227.9 & 2054.1 & 526.6 \\
\hline & Slab & 28.9 & 30.8 & 28.3 & 20.2 & 10.6 & 118.7 & \\
\hline & Railling & 0.0 & 0.0 & 0.0 & 0.0 & 156.7 & 156.7 & \\
\hline & Total & 555.4 & 529.0 & 475.9 & 374.1 & 395.2 & 2329.6 & 529.0 \\
\hline \multirow{4}{*}{$2 \mathrm{R}$} & Girder & 353.6 & 398.1 & 398.6 & 339.0 & 238.0 & 1727.3 & 398.6 \\
\hline & Slab & 23.1 & 30.0 & 29.0 & 21.2 & 11.8 & 115.2 & \\
\hline & Railling & 305.5 & 0.0 & 0.0 & 0.0 & 181.6 & 487.1 & \\
\hline & Total & 682.2 & 428.2 & 427.6 & 360.3 & 431.4 & 2329.6 & 428.2 \\
\hline
\end{tabular}

Table 1 shows a typical summary of those moments for the $80 \mathrm{ft}(24 \mathrm{~m})$ span, $6 \mathrm{ft}(1.8 \mathrm{~m})$ girder spacing with standard railings (x1) at either or both sides of the bridge deck; the case with no railing is also shown for reference. The maximum FEA moments in the critical interior girder $\left(M_{\max }\right)$ for the latter bridge cases can be obtained for each railing configuration (NoR, RL, RR, and 2R) by combining girder and slab moments; this is shown in the "MaxTotal" value in the last column of the table. It is also worth noting that the total moment summed from all girders, slabs, and railings, or "Total-Total", is the same for all railings configurations, and is equal to four times the maximum statical girder moment $\left(M_{o}\right)$ obtained from 2D-beam analysis with one line of wheel loads applied, for all the two-lane bridges.

The wheel load distribution factor (DF) from FEA was calculated by dividing the maximum FEA moment in the critical interior girder $\left(M_{\max }\right)$, considering the combination of moments from steel girder and concrete slab, by the maximum girder moment $\left(M_{o}\right)$, or DF $=M_{\max } / M_{o}$. This FEA DF for interior girders for the bridge cases with various configurations and sizes of railings will be compared with the DF from AASHTO Standard formula ("S/5.5") and LRFD Eq. (1), as well as with the reference bridges without railings, in order to determine the effect of these elements on the bridge superstructure. The maximum statistical girder moment $\left(M_{o}\right)$ and FEA wheel load DF for interior girders are summarized in Table 2 for the two-lane bridge cases considered, for all span lengths and girder spacing analyzed with standard railings (x1) at either or both sides of the bridge deck, including the case with no railing as a reference. The FEA wheel load DF are also plotted with the span lengths in Fig. 5, along with AASHTO Standard formula ("S/5.5”) and AASHTO LRFD Eq. (1) for the two-lane bridges with $6 \mathrm{ft}(1.8 \mathrm{~m})$ girder spacing and standard railing stiffness (x1). Finally, Table 3 shows the maximum interior AASHTO and FEA DF for all 240 bridge cases, with the various railings stiffness considered in this study.

\section{ANALYSIS OF RESULTS}

For the particular bridge cases shown in Table 1 of the two-lane bridges with $80 \mathrm{ft}(24 \mathrm{~m})$ span and 6 $\mathrm{ft}(1.8 \mathrm{~m})$ girder spacing, the FEA results shows that the contribution of bending moment from the concrete slab is about $5 \%$ to the overall total girder bending moment when there is no railing on the bridge. It was also observed that this percentage contribution ranges from about $5 \%$ to $15 \%$ for other two-lane bridge cases considered with no railing. However, when introducing railing or parapet on one 
Table 2 FEA distribution factors in interior girders for two-lane bridges with standard railings (x1)

\begin{tabular}{|c|c|c|c|c|c|c|}
\hline \multicolumn{7}{|c|}{ Mo (kip-ft) and FEA DF, Interior Steel + Slab, Two Lanes, Standard Railings (x1) } \\
\hline $\mathrm{L}(\mathrm{ft})$ & $\mathrm{S}(\mathrm{ft})$ & Mo (kip-ft) & DF-NoR & DF-RL & DF-RR & DF-2R \\
\hline \multirow{3}{*}{40} & 6 & 224.8 & 1.05 & 1.05 & 1.05 & 1.05 \\
\hline & 8 & 224.8 & 1.36 & 1.31 & 1.36 & 1.31 \\
\hline & 12 & 224.8 & 1.91 & 1.88 & 1.90 & 1.86 \\
\hline \multirow{3}{*}{60} & 6 & 403.2 & 0.95 & 0.87 & 0.95 & 0.84 \\
\hline & 8 & 403.2 & 1.20 & 1.07 & 1.19 & 1.05 \\
\hline & 12 & 403.2 & 1.58 & 1.46 & 1.50 & 1.37 \\
\hline \multirow{3}{*}{80} & 6 & 582.4 & 0.92 & 0.79 & 0.91 & 0.74 \\
\hline & 8 & 582.4 & 1.14 & 0.95 & 1.10 & 0.91 \\
\hline & 12 & 582.4 & 1.48 & 1.29 & 1.35 & 1.15 \\
\hline \multirow{3}{*}{100} & 6 & 825.4 & 0.89 & 0.74 & 0.87 & 0.68 \\
\hline & 8 & 825.4 & 1.10 & 0.90 & 1.04 & 0.83 \\
\hline & 12 & 825.4 & 1.43 & 1.20 & 1.26 & 1.02 \\
\hline \multirow{3}{*}{120} & 6 & 1163.5 & 0.87 & 0.71 & 0.84 & 0.65 \\
\hline & 8 & 1163.5 & 1.07 & 0.87 & 1.00 & 0.77 \\
\hline & 12 & 1163.5 & 1.39 & 1.14 & 1.20 & 0.94 \\
\hline
\end{tabular}

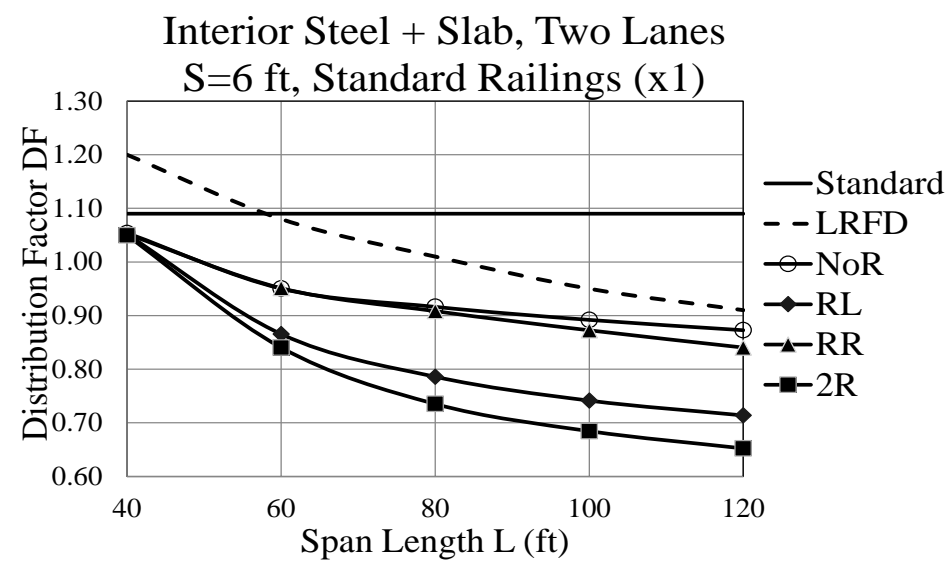

Fig. 5 AASHTO and FEA distribution factors in interior girders for two-lane bridges with $6 \mathrm{ft}$ girder spacing and standard railings (x1)

or both sides of the bridge deck, the concrete slab and railing contribute largely to the total bending moment of the exterior girder in bridges, which can reaches about 50\% with the standard railing stiffness (x1) for the bridge cases shown in Table 1. The FEA moments results in exterior girders showed that the percentage of the deck contribution (slab and railing) to the overall moments increased due to changes in railing stiffness and span lengths, but not with girder spacing, ranging from about $25 \%$ to $35 \%$ for (x0.5), $35 \%$ to $50 \%$ for (x1), $40 \%$ to $65 \%$ for (x2), $40 \%$ to $75 \%$ (x3), and $45 \%$ to $80 \%$ for (x4).

In this study, since the AASHTO HS20 trucks were placed $2 \mathrm{ft}(0.60 \mathrm{~m})$ from the left outside girder, the maximum bending moment predicted to occur in either one of the two left side girders, except for the shortest span, where in the case of $6 \mathrm{ft}(1.8 \mathrm{~m})$ girder spacing, the maximum was always at the center girder. Therefore, when the railings were placed on the left side or on both sides of the bridge, the maximum bending moment occurred in the left exterior girder when adding the contribution of the railing but, as discussed earlier, the effective critical girder will be an interior one. As a result, the wheel load DF to be used in the girders will be identified based on the maximum moment occurring in the interior critical girder.

This FEA maximum design moment or FEA-DF will therefore be compared with AASHTO 
Table 3 AASHTO and FEA distribution factors in interior girders for all bridges with various railings stiffness

\begin{tabular}{|c|c|c|c|c|c|c|c|c|c|c|c|c|c|c|c|c|c|c|c|}
\hline \multicolumn{20}{|c|}{ AASHTO and FEA DF, Interior Girders (Steel + Slab), Two Lanes, All Railings Stiffness } \\
\hline \multirow{2}{*}{$\mathrm{L}(\mathrm{ft})$} & \multirow{2}{*}{$\mathrm{S}(\mathrm{ft})$} & \multirow{2}{*}{ Stand. } & \multirow{2}{*}{ LRFD } & \multirow{2}{*}{ NoR } & \multicolumn{5}{|c|}{$\mathrm{RL}$} & \multicolumn{5}{|c|}{ RR } & \multicolumn{5}{|c|}{$2 \mathrm{R}$} \\
\hline & & & & & $\mathrm{x} 0.5$ & $\mathrm{x} 1$ & $\mathrm{x} 2$ & $\mathrm{x} 3$ & $\mathrm{x} 4$ & $\mathrm{x} 0.5$ & $\mathrm{x} 1$ & $\mathrm{x} 2$ & $\mathrm{x} 3$ & $\mathrm{x} 4$ & $\mathrm{x} 0.5$ & $\mathrm{x} 1$ & $\mathrm{x} 2$ & $\mathrm{x} 3$ & $\mathrm{x} 4$ \\
\hline \multirow{3}{*}{40} & 6 & 1.09 & 1.20 & 1.05 & 1.05 & 1.05 & 1.05 & 1.05 & 1.05 & 1.05 & 1.05 & 1.05 & 1.05 & 1.05 & 1.05 & 1.05 & 1.05 & 1.05 & 1.05 \\
\hline & 8 & .46 & 1.48 & 1.36 & 1.32 & 1.31 & 1.30 & 1.30 & 1. & 1.36 & 1.36 & 1.36 & 1.36 & 1.36 & 1.32 & 1.31 & 1.30 & 1.30 & 1.30 \\
\hline & 12 & .18 & 1.98 & 1.91 & 1.89 & 1.88 & 1.87 & 1.87 & 1. & 1.90 & 1.90 & 1.89 & 1.89 & 1.89 & 1.87 & 1.86 & 1.85 & 1.85 & 1.85 \\
\hline \multirow{3}{*}{60} & 0 & 1.09 & .08 & 0.95 & 0.88 & 0.87 & 0.85 & 0.85 & 0.84 & 0.95 & 0.95 & 0.95 & 0.95 & 0.95 & 0.86 & 0.84 & 0.82 & 0.81 & 0.80 \\
\hline & 8 & 1.46 & 1.32 & 1.20 & 1.11 & 1.07 & 1.02 & 1.00 & 0.99 & 1.19 & 1.19 & 1.18 & 1.18 & 1.18 & 1.10 & 1.05 & 1.00 & 0.97 & 0.96 \\
\hline & 12 & 2.18 & 1.77 & 1.58 & 1.49 & 1.46 & 1.42 & 1.40 & 1.3 & 1.53 & 1.50 & 1.48 & 1.47 & 1.47 & 1.44 & 1.37 & 1.31 & 1.28 & 1.26 \\
\hline \multirow{3}{*}{80} & 6 & 1.09 & 1.01 & 0.92 & 0.81 & 0.79 & 0.76 & 0.74 & 0.7 & 0.91 & 0.91 & 0.91 & 0.90 & 0.90 & 0.80 & 0.74 & 0.68 & 0.65 & 0.63 \\
\hline & 8 & 1.46 & 1.23 & 1.14 & 1.02 & 0.95 & 0.92 & 0.91 & 0.9 & 1.11 & 1.10 & 1.09 & 1.08 & 1.08 & 0.99 & 0.91 & 0.82 & 0.77 & 0.74 \\
\hline & 12 & 2.18 & 1.64 & 1.48 & 1.35 & 1.29 & 1.22 & 1.19 & 1.17 & 1.39 & 1.35 & 1.31 & 1.28 & 1.27 & 1.26 & 1.15 & 1.03 & 0.97 & 0.93 \\
\hline \multirow{3}{*}{100} & 6 & 1.09 & 0.95 & 0.89 & 0.78 & 0.74 & 0.70 & 0.69 & 0.69 & 0.88 & 0.87 & 0.86 & 0.86 & 0.86 & 0.76 & 0.68 & 0.59 & 0.54 & 0.51 \\
\hline & 8 & 1.46 & 1.16 & 1.10 & 0.97 & 0.90 & 0.86 & 0.85 & 0.83 & 1.06 & 1.04 & 1.02 & 1.01 & 1.00 & 0.93 & 0.83 & 0.70 & 0.63 & 0.59 \\
\hline & 12 & 2.18 & 1.54 & 1.43 & 1.28 & 1.20 & 1.11 & 1.06 & 1.03 & 1.32 & 1.26 & 1.19 & 1.16 & 1.14 & 1.17 & 1.02 & 0.86 & 0.77 & 0.72 \\
\hline \multirow{3}{*}{120} & 6 & 1.09 & 0.91 & 0.87 & 0.76 & 0.71 & 0.68 & 0.67 & 0.66 & 0.85 & 0.84 & 0.83 & 0.82 & 0.81 & 0.74 & 0.65 & 0.54 & 0.47 & 0.43 \\
\hline & 8 & 1.46 & 1.10 & 1.07 & 0.94 & 0.87 & 0.82 & 0.80 & 0.78 & 1.02 & 1.00 & 0.96 & 0.94 & 0.93 & 0.89 & 0.77 & 0.63 & 0.55 & 0.50 \\
\hline & 12 & 2.18 & 1.47 & 1.39 & 1.23 & 1.14 & 1.03 & 0.97 & 0.93 & 1.27 & 1.20 & 1.11 & 1.07 & 1.04 & 1.11 & 0.94 & 0.76 & 0.65 & 0.59 \\
\hline
\end{tabular}

procedures/equations, with and without railings. Also, the maximum FEA-DF for cases with railings on either edge or both edges will be compared with the reference FEA-DF cases without railing for all railings stiffness considered. Note that for exterior girders, the railings when present should be designed to take the large moments attracted to those stiffening elements.

\subsection{FEA Results vs. AASHTO Procedures}

As shown in Table 3, AASHTO Standard [1] formula is highly conservative when compared with the FEA DF without railing which was also previously reported [3] for all the two-lane bridge cases considered. This will be even more the case with any railing size. This study will therefore focus on comparing the FEA DF with AASHTO LRFD [2] Eq. (1), where a good correlation in the pattern of results was observed as shown in Fig. 5. Using Table 3 , the following general observations can be made:

- $\quad$ No railing (NoR): FEA DF were smaller than Eq. (1) by about $10 \%$ for spans up to $80 \mathrm{ft}(24 \mathrm{~m})$, and by about 5\% for spans between 80 and 120 $\mathrm{ft}$ (24 to $36 \mathrm{~m}$ ).

- $\quad$ Railing on one side (Largest of RL or RR): FEA DF were smaller than Eq. (1) by about: $10 \%$ for railing stiffness (x0.5), 15\% for railing stiffness (x1) and (x2), and 20\% for railing stiffness (x3) and (x4).

- Railings on both sides (2R): FEA DF were smaller than Eq. (1) by about: 20\% for railings stiffness (x0.5), 30\% for railings stiffness (x1), $45 \%$ for railings stiffness (x2), 50\% for railings stiffness (x3), and 60\% for railings stiffness (x4).

\subsection{Influence of Railings Stiffness vs. Reference Base Cases without Railing}

Using Table 3, the following general observations can be made:

- $\quad$ Railing on one side (Largest of RL or RR): FEA $\mathrm{DF}$ with one railing is reduced when compared to reference case without railing by an average of about: $5 \%$ and $10 \%$ for railing stiffness (x0.5) through (x4) for spans between 40 and $80 \mathrm{ft}$ (12 to $24 \mathrm{~m}$ ), and $10 \%$ and $20 \%$ for railing stiffness (x0.5) through (x4) for spans for spans between 80 and $120 \mathrm{ft}$ (24 to $36 \mathrm{~m}$ ).

- Railings on both side (2R): FEA DF with two railings is reduced when compared to reference case without railing by an average of about: $10 \%$ and 30\% for railings stiffness (x0.5) through (x4) for spans between 40 and $80 \mathrm{ft}$ (12 to $24 \mathrm{~m}$ ), and $15 \%$ and $50 \%$ for railings stiffness (x0.5) through (x4) for spans for spans between 80 and $120 \mathrm{ft}$ (24 to $36 \mathrm{~m}$ ).

\section{SUMMARY AND CONCLUSIONS}

A parametric study using finite-element analysis was performed to investigate the influence of railing stiffness on wheel load distribution in simplysupported, one-span, two-lane steel girder bridges. The bridge parameters considered were the span length, girder spacing, and railings stiffness and configurations, subject to HS20 truck loadings positioned transversally and longitudinally in order to 
produce maximum girder bending moments.

The effect of railing stiffness on the maximum live load wheel load distribution factors were assessed by calculating and comparing the FEA moments or wheel load distribution factors with both AASHTO Standard and LRFD, as well as with the reference bridge cases without railing. The study confirmed that AASHTO Standard [1] formula is highly conservative when compared with the FEA DF without railing or with railings, and that FEA DF were smaller than AASHTO LRFD [2] Eq. (1) by about $5-10 \%$ with no railing, to about $20-50 \%$ for two railings with stiffness $(\mathrm{x} 0.5)$ to $(\mathrm{x} 4)$, depending on span lengths. The study also showed that the presence of one or two railings reduces the FEA-DF about 5$20 \%$ or $10-50 \%$, respectively, depending on railings stiffness and span length. Such reduction in DF due to railings implies an increase in the bridge. Therefore, bridge engineers can consider adding, replacing, or stiffening railings/parapets as a practical method for strengthening existing steel girder bridges.

\section{ACKNOWLEDGMENTS}

This research was supported by a grant from the University Research Board (URB) at the American University of Beirut to whom the authors are indebted and thankful.

\section{REFERENCES}

[1] American Association of State Highway and Transportation Officials (AASHTO), Standard Specifications for Highway Bridges, 17th ed, Washington D.C., 2002.

[2] American Association of State Highway and
Transportation Officials (AASHTO), LRFD Bridge Design Specifications, 7th ed, Washington D.C., 2014.

[3] Mabsout M., Tarhini K., Frederick G., and Tayar C., Finite Element Analysis of Steel Girder Highway Bridges, Journal of Bridge Engineering, ASCE, Vol. 2, No. 3, 1997, pp. 83-87.

[4] Mabsout M., Tarhini K., Frederick G., and Kobrosly M., Influence of Sidewalks and Railings on Wheel Load Distribution in Steel Girder Bridges, Journal of Bridge Engineering, ASCE, Vol. 2, No. 3, 1997, pp. 88-96.

[5] Chung W., Liu J., and Sotelino E.D., Influence of Secondary Elements and Deck Cracking on the Lateral Load Distribution of Steel Girder Bridges, Journal of Bridge Engineering, ASCE, Vol. 11, No. 2, 2006, pp. 178-187.

[6] Conner S. and Huo X.S., Influence of Parapets and Aspect Ratio on Live-load Distribution, Journal of Bridge Engineering, ASCE, Vol. 11, No. 2, 2006, pp. 188-196.

[7] Akinci N.O., Liu J., and Bowman M.D., Parapet Strength and Contribution to Live Load Response for Superload Passages, Journal of Bridge Engineering, ASCE, 13(1), 2008, pp. 55-63.

[8] Roddenberry M.R., Chipperfield J., and Tawfiq, K.S., Effect of Secondary Elements on Load Distribution in Prestressed Bridge Girders, Structures Congress, ASCE, pp. 215-226.

[9] SAP2000, User's Manual, Computers and Structures Inc., Berkeley, California, 2017.

Copyright (C) Int. J. of GEOMATE. All rights reserved, including the making of copies unless permission is obtained from the copyright proprietors. 